\title{
Russ Ladwa: 'I've always stood up for people who can't speak for themselves'
}

\author{
Interview by Kate Quinlan
}

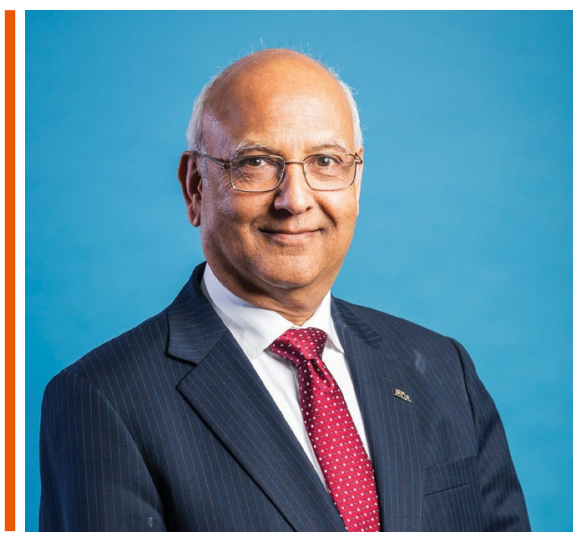

Russ Ladwa took office as 134th President of the British Dental Association (BDA) on 16 September 2020. After a happy childhood in Kenya, Russ moved to the UK to study dentistry and qualified from the London Hospital Medical College in 1975.

A former Dean of the Faculty of General Dental Practitioners, Russ has chaired both the Federation of London Local Dental Committees and the Dental Vocational Training Authority, and was a board member of the Odontology section of the Royal Society of Medicine before being made its President. In 2012, having been a lifelong member of the BDA, Russ was elected to the Principal Executive Committee (PEC), serving until 2019.

\section{Why did you choose to become a dentist? Were there dentists among your close family?}

No, I didn't have any dentists in the family, I was the first one. What I wanted to do when I came to the UK was study medicine, but I couldn't get a place. Then a lot of my friends were going into dentistry, so I applied too and I got in through clearing.

\section{Was coming to London to study after your childhood in Kenya a culture shock? \\ Yes, in all respects. As regards the studying, I always joke that I didn't do well in my first year at dental school because I discovered beer and girls. But nearer the truth is that the way we were taught in Kenya at school was to learn a lot of things by rote, for example I could recite a lot of Shakespeare's Twelfth Night which I did for O-level. We weren't always taught to work things out for ourselves or think for ourselves, so that was certainly a change coming to the UK.}

\section{Do you still go back to Kenya to visit?}

I have been to show my wife and my daughters my old school, etc, and I've been back to lecture for the Kenya Dental Association and to set up a study group for the faculty; I renewed my links there.
I was born and brought up inland in the Rift Valley in Nakuru, in the middle of the farming community. Nakuru is a town famous for its big flamingo lake, a small town of perhaps 40-50,000 people, and at that time it didn't even have any traffic lights.

When I took my family over to visit and we travelled and visited the game reserves and safari parks, we also went to see my wife's father's school in Mombasa and his name was still on the board. My daughters saw my school on that trip too. When they were younger, my daughters used to pick me up on my pronunciation of certain words that they said I got wrong. My excuse was always to say to them that they had the benefit of a private school education and all I did was go to school under a mango tree. When they saw my actual school they then said I had been lying to them all my life!

\section{Did you always plan to go into general dental practice as opposed to specialising?}

After graduation I had a short house job at the London, and then a very short stint with the American Army in Germany as a civilian dentist. This was when I realised that London and the UK had become home and I missed it. I came back and thought about going to the USA to specialise in endodontics or restorative dentistry, but I started working in general practice, then got married, and didn't get round to specialising. What I found is that it worked well for me because, as a general dentist, I enjoy the variety and all the time it has given me to get involved with all the education and training and professional issues that I have managed to engage with.

The other good thing about general practice is that I have seen generations of children grow, and now they come with their own children to see me. It is that continuity over generations that perhaps I might not have had in a specialist practice.

\section{When do you think that your passion for} improving oral health emerged?

I think that it evolved over a period of time. The starting point was I enjoyed and loved my dentistry and everything associated with it. Then, because I always wanted to be involved in other things besides the clinical practice, because I enjoyed writing, meeting people, communication and the professional side of it, as it were, one thing led to another. It was the right progression to then promote oral healthcare. 


\section{You became involved with the BDA at section level when you felt isolated after starting your own practice in 1977. What did this involvement provide you with?}

During my first year in general practice I had set up a dental nurses' course at Acton College which I taught for the first year, then handed over to somebody, and I think that course is still running. It is that sort of outside involvement which I always enjoyed. When I first went to the Ealing and Acton Section of the BDA which met at Central Middlesex, there were 10-12 white, elderly male dentists in the Section who adopted me and helped and encouraged me greatly. Within weeks I was a Section Officer and within months I was on the LDC and ended up being on the then Family Practitioner Committee, which was interesting.

Working with the BDA section, then we used to have joint meetings with the remarkable postgraduate dental tutor Gabby Goubran at Central Middlesex Hospital and from time to time when he was away, I used to stand in for him. When he had to retire early for personal reasons, he really pushed for me to be his successor. At that time it wasn't normal for a general dental practitioner to be a postgraduate tutor; normally it was a hospitalbased oral surgeon or orthodontist. In 1990, I was made a postgraduate tutor which was novel in those days.

And then with the Faculty of General Dental Practice being founded in 1992, I was invited - with Ashok Sethi, also from Ealing - to be a founding member.

So the BDA Section has really been my springboard and my passport to the outside world.

\section{Have you enjoyed your extensive involvement with committees, boards and groups over your career? Do you thrive on contributing to many different ventures?}

Yes, I do. I think I like the involvement with my patients more than anything else, but I also like the variety of issues and institutions that I have had the privilege to be involved with. I like people, I like communicating, I like writing and I enjoy public speaking.

My father got me speaking in public at the age of ten which has set me in good stead because now I can do it quite easily. All these things were - without realising it preparations for perhaps a more involved and committed future.
You opened your current practice in Ealing in 1985. Is this also your residence? Yes. It was an established practice, on the ground floor, and it has been there for 70 or 80 years. I'm the fourth dentist and live above. The first one or two dentists used to treat the actors from Ealing Studios in those heady days.

I took over from Fred Harty who was an Australian endodontist who sadly died in a car crash in Australia... he also started the Lister House dental practice on Wimpole Street.

\section{How do you think the practice has changed over the 36 years that you have been there?}

It has changed in that the demographics of Ealing have changed. We've had a Polish influx and before that we had refugees from Somalia and before that was Iranians - so Ealing has had these cohorts of changing populations. In my early days I treated a lot of Japanese families, so much so that I had to go and buy a Japanese dictionary so that I could communicate with the mothers and children.

Living above the practice I can manage emergencies more easily.

The other thing I find great about it is that I see the whole cross-section of society come to me without me having to go out.

\section{Your daughter now works alongside you at the family practice. Are you proud that she has followed you into dentistry?}

I'm extremely proud. Initially, I was disappointed because my older daughter Meera went into medicine. Radhika went to the LSE to study economics and geography. But when she ended up working in accounting, marketing, banking and consultancy, all office based, she soon realised that really what she would have liked is more personal context and practical work. She came back to us at 25 and said she wanted to study dentistry. She worked very hard, and then ended up with a distinction at King's, which I never had!

\section{Was it interesting to compare your daughter's experience of dental education with your own, as a lot must have changed since the 1970s?}

Oh, absolutely. From when she started at dental school I was changing my practice, even at that early stage, when she told me what the best bonding agent was, and I was using something different. We had some debate about some of the procedures I was doing. Initially, I found it very difficult to get rid of some of the methods that I had been using for such a long time because that worked for me, but when I saw the research and the evidence, then I did change. This was for the better: I think my patients have much better treatment because I've been upgraded and updated regularly.

\section{Are you partners or are you the boss?}

She's my boss! In the sense that she tells me what to do about a lot of things. When my daughter first joined the practice, I thought she was going to be very impressed with how well I did things until she said to me 'well, that first patient, you didn't take proper consent'; 'the next patient you didn't give all the options'; 'this patient, you didn't use the latest technique'. It was a bit odd. But I have been open to being educated, so it has worked well.

At the moment, technically my daughter is an assistant, but really we are partners. I'm hoping that in the next few months, she will take over. And I will do less and less clinical work.

What I will miss is the connection with the patients and chatting to them. I have been telling them that when I'm not doing the clinical work, they will see my daughter first for the fillings, and then they'll come up and have a coffee with me.

I was 70 last year. When my hands and eyes are not as good as they should be I will have to cut down on the clinical work. At some stage I will then have to reluctantly ride into the sunset.

\section{How did it feel to become BDA President?}

I was extremely proud; it was the best seventieth birthday present anybody could have ever given me. So it was a double celebration!

I think that for a general practitioner from the suburbs, who's had an unusual journey, the presidency was a recognition of general practitioners and also a declaration that people with different backgrounds and journeys can still get there.

\section{What are the main things that you hope to achieve in your presidential year?}

Presidents have a theme, and because I like so many different things, my presidency could have been about professionalism or leadership or education and training, or even sustainability, or obviously equality and diversity. However, in the days I was still on the PEC and I was nominated as President Elect, 
because of my two daughters and the fact that $50 \%$ of the profession and the membership are now female, I was very happy to support women's issues and support them to be represented at all levels. But then the Black Lives Matter movement happened so we've got the racism issue added on to that, and I've taken up the cudgels. That has happened in a sense by default, but I'm comfortable to do that.

In your presidential address, you said that as president you hoped to build bridges with the CDOs, the dental faculties of the Royal Colleges and whoever else necessary to lead on oral health. Are you making progress with these goals?

Yes, but because of the pandemic and not being able to go and see people, it's limited because you are communicating only by email or telephone. I have tried to keep the presidency as an aside from the politics. I think personal contacts always help you to do things, especially to do things in the background. So I've got very good contacts with the deans at the Royal Colleges, their friends and peers. I've also got very good contacts with the $\mathrm{CDO}$, and her officers, but what I could have done, sitting face-to-face with somebody and looking into their eyes is not possible by email and telephone. It may still be possible if things open up before my term ends.

\section{It's clear diversity and inclusion are issues that are close to your heart. How have you explored and acted upon these issues as President?}

Well, I've jumped into it all with full heart, mind and energy because all the other things I could have done as President by travelling etc are out. When the PEC founded the Equalities, Diversity and Inclusion Committee (EDIC), I was invited to chair it. But as President I thought I should step aside and help and support them, but not enrol as chairperson because it is a sensitive and emotional issue. So, then the PEC rightly chose Shareena Ilyas and Laura Cross as co-chairs. But I contribute, advise, support and possibly direct as much as I can, as required.

\section{What topics will be on the agenda for the new EDIC committee?}

What I said to the PEC when this committee was founded was that we cannot change the world overnight; we should have some sort of plan: what we can do immediately, what we can do in the mid-term, and what we can get in the long-term. So we should start immediately in-house, make our own $\mathrm{BDA}$ as robust as possible, get all the small gains we can and then go on to the rest of the profession before the rest of society. We should have some sort of strategy but at the same time, I think we should be seen to be doing the practical and immediate things, soon, rather than just talking about it. The PEC and the Committee have taken that up. So, while we are continuing to look at ourselves first, we are also working with the CDO and the Faculty because this is a profession-wide and a society-wide issue, and also watching what the Royal Colleges, the BMA and the other professions are doing.

\section{Do you wish that you might have been BDA President in an ordinary year with no pandemic?}

Well that would have been nice because I would have loved to go to all the sections and branches, meet people I've known for a long time but maybe lost touch, and renew my links abroad with others that I've made during my career. Of course, it's the way things have worked out, but I've missed that. I'm also very philosophical about it, in the sense that if there are people dying in the world, and we are facing a major crisis, I'm very fortunate I can still work and continue to provide dental care.

\section{How long do you think it will take for dentistry to recover from the effects of the pandemic?}

I think it will be a long time because at the last count you're looking at well over 20 million appointments missed. We may have missed a lot of gum disease, and decay must have got worse. Children's general anaesthetic lists are getting longer and we are also worried about the mouth cancer cases missed - and this is one of the few cancers which is rising in numbers. This pandemic is going to be a disaster for dentistry and oral care throughout the world.

I think that while the Department of Health supported NHS dentists very well initially, if the whole NHS is going to be revamped, why leave out dentistry? There has been a great missed opportunity... If there's been a creaking contract, an arrangement that hasn't been good for the profession or good for the patients but it's still allowed to carry on, then a demoralised profession under stress is not in a good place to go back and look after people [post-pandemic]. I've always said, whether you're a doctor or dentist or nurse, unless you're healthy and happy in your own mind, you cannot do your best for your patients.

\section{What do you think needs to be done to get oral health back on track for all communities in the UK?}

I think that dentists have tried to cope as best as they can. My practice and all of the others closed down for the first lockdown from the end of March for ten weeks. In that time, I felt very helpless because a lot of these hospitals or urgent dental care centres were doing the basic minimum, and some patients lost some teeth that they shouldn't have lost. We have tried to catch up with treatments as much as we can, but our efficiency with the fallow times and the requirements for PPE has been reduced to less than $50 \%$ even in a small practice like mine.

I think that NHS dentists were quite well supported. I hope that support continues, because the private practices weren't. Whether NHS or private, they are all ultimately businesses and if there hasn't been enough income, then there's not enough reinvestment in the business. The effects will be long lasting and it will take a considerably long time to get back into a normal world, if we are ever to have a 'normal' world as we knew it.

Over the past year you must have stayed at home more than ever before. Have you enjoyed it in some respects?

A lot more. It has been quite good in some respects because it has given people a chance to reflect.

I did a lot more working in the garden. My wife and daughter are both keen gardeners and I helped out doing the heavy duty gardening digging, cutting and lifting. Doing something of common interest like that was nice and it was a good team/family effort.

I always liked gardening to see things grow from the time of my childhood in Africa. It's something I hope to do more of in the future.

\section{How else do you like to spend your spare time?}

I do a fair bit of walking. I like films and reading. I say it guardedly but from about the age of ten, I've asked myself 'why am I here in this world?' Every time something happens, I may find another piece of the jigsaw to fit. But, I'm in the stage of life where I think perhaps there's no answer; the fact that I keep on asking the question is more important. 


\section{Do you have any unfulfilled ambitions you'd like to share?}

I'd like to say that in the past, I used to want to see my name in print, at meetings etc. That ego and ambition is sated now. I feel very fulfilled with the BDA presidency. I've gone as high as I can get, and I'm satisfied with that.

I'd like to write a book. I've written lots of papers and book chapters for others but I've never had my name to a book. One of the things I've already talked to my publisher friend about is an account of my first 18 years in Kenya. Many East African Asians have migrated throughout the world. Some of the things that I observed that I would write about may strike a chord and be of interest to many of these people.

\section{What are you most proud of?}

My family, my profession, the BDA, and all the people who helped me get to where I am.

\section{What do you hope to do once the pandemic restrictions are fully lifted?}

Catch up with meeting my nieces' children - the closest we have to grandchildren and catching up with friends and family members. Having a meal and a chat and catching up in person that we haven't been able to do.

When we are allowed to travel, I am looking forward to visiting sections and branches as well.

\section{What do you hope to be remembered for in your year as BDA President?}

I'm very much hoping that I will be remembered for the equality and diversity issues that I'm well involved with. If I carry on as best as I can, for the rest of my term, I'm hoping that the BDA will allow me to continue contributing and be involved with these issues, even when I step down.

\section{What do you think spurs you on and keeps you going?}

I think staying positive is the key. From a very young age, I have felt that I must have a purpose in this life. I am always positive about things - I think there is always hope even with the current pandemic. We've had pandemics in the past. Nothing has lasted forever; we may come out to some sort of normality, despite the severe loss of life. I think that things will get better, things will improve. Whether it will ever be 'normal' as we knew it, I don't know.

My faith has always made me value my life and respect others. I've always stood up for people who can't speak for themselves. I haven't always shared my stories but now I'm happier to do so because I'm told that it's a way of having an impact, giving others hope that it is possible for them to get there as well. They're not in isolation and what I have to say carries more weight now, due to my current post. It is vital for me to speak up now, otherwise it would be a wasted opportunity. I think one needs that fire in the belly. It may be a very slow fire, but it's always there!

\section{Would you recommend a career in dentistry to youngsters today?}

Oh, absolutely. I think dentistry is a very challenging career with so many disciplines, so many skills, so many different sides to it, and yet such a flexible career. I would 150\% recommend it. Even with artificial intelligence and all the new technologies, you will still need human dentists for some time yet. 